\title{
The Effect of Feeding a Dry Enzyme Mixture with Fibrolytic Activity on the Performance of Lactating Cows and Digestibility of a Diet for Sheep
}

\author{
M. A. Reddish and L. Kung Jr. ${ }^{1}$ \\ Delaware Agricultural Experimental Station, Department of Animal and Food Sciences, College of Agriculture and Natural Resources, \\ University of Delaware, Newark 19716-2150
}

\section{ABSTRACT}

A dry enzyme mixture was added to the diets of lactating cows and growing lambs to evaluate its ability to improve milk production and nutrient digestibility, respectively. The enzyme mixture contained xylanase and cellulase activity over a broad range of $\mathrm{pH}$ (tested from 4 to 7). Twenty-four lactating cows between 50 and $150 \mathrm{~d}$ in milk and averaging about $40 \mathrm{~kg}$ of milk/ $\mathrm{d}$ were fed a total mixed ration (TMR) consisting of $26 \%$ [dry matter (DM) basis] corn silage, $17 \%$ alfalfa silage, $7 \%$ chopped alfalfa hay, and 50\% concentrate. One-half of the cows were fed the TMR without supplementation and the remaining half of the cows were fed the same TMR supplemented with $10 \mathrm{~g}$ of the enzyme mixture/ cow per day. After $21 \mathrm{~d}$, the treatments were crossed over for a second 21-d period. The dry enzyme mixture had no effect on DM intake, milk production, or milk composition. Addition of various concentrations of the enzyme mixture did not improve the in vitro digestion of neutral detergent fiber from the TMR. In a digestion trial, lambs were fed a commercial diet supplemented with $4 \mathrm{~g}$ of the enzyme mixture/lamb per day, and total feces and urine were collected. Although the ratio of enzyme to feed was much higher than it was in the experiment with lactating cows, addition of the enzyme mixture had no effect on the apparent digestion of DM, acid detergent fiber, neutral detergent fiber, or $\mathrm{N}$ in the diet.

Key words: enzyme, dairy cow, cellulase, xylanase

\section{INTRODUCTION}

Adding fibrolytic enzymes to the diets of ruminant animals has been the topic of many recent studies. Morgavi et al. (2000a) suggested that spraying fibrolytic enzymes on dry feeds improved rumen digestion via a

Received April 10, 2007.

Accepted June 7, 2007.

${ }^{1}$ Corresponding author: lksilage@udel.edu synergy between added enzyme activity and enzyme activity in the rumen supplied by its microorganisms. Research has shown that some enzymes are protected from proteolytic degradation in the rumen (Hristov et al., 2000) because of extensive glycosylation (Fontes et al., 1995).

Fibrolytic enzymes have been solubilized in water and sprayed directly onto feeds before feeding (Lewis et al., 1999; Beauchemin et al., 2000). Indices of in vitro digestion (Kung et al., 2002; Colombatto et al., 2003) and in vivo digestion (Rode et al., 1999; Yang et al., 1999) have been improved in several studies when liquid-based enzymes have been sprayed onto feeds, but improvements in milk production have not always been consistent (Stokes and Zheng, 1995; Schingoethe et al., 1999; Beauchemin et al., 2000).

In contrast to studies applying enzymes in a liquid form directly onto the feed, there have been studies that evaluated the effects of adding enzymes in a dry form to the diets of ruminants. Zinn and Salinas (1999) reported increases in ruminal digestion of NDF and feed $\mathrm{N}$ by 23 and $5 \%$, respectively, when dry enzymes were added to the diet. They also reported an improvement in DMI and ADG in steers supplemented with enzymes. Ballard et al. (2003) reported that adding dry enzymes to the diet of lactating dairy cows increased the digestion of DM, OM, and NFC, but there were no effects on milk production and milk composition. In contrast, Ahn et al. (2003) reported an $8 \%$ increase in milk production when a dry enzyme supplement was fed to dairy cows.

The objectives of this study were to evaluate further the effect of feeding fibrolytic enzymes in a dry form to lactating cows on milk production and composition and to evaluate the effect on digestibility of a diet for sheep.

\section{MATERIALS AND METHODS}

\section{Animal Care}

All animals and experimental protocols used in the following studies were approved by the University of 
Delaware, College of Agriculture and Natural Resources, Agricultural and Animal Care and Use Committee, and followed the guidelines of the Guide for the Care and Use of Agricultural Animals in Agricultural Research and Teaching (FASS, 1999).

\section{Enzyme Mixture}

A noncommercial formulation of enzymes containing cellulase and xylanase activity (Alltech Inc., Nicholasville, KY) was used for these studies. Activity of the enzyme mixture was determined by Agriculture and Agri-Foods Canada (Lethbridge, Alberta, Canada) using azo-xylan and azo-carboxymethyl cellulose (Megazyme, Co. Wicklow, Ireland) as substrates. Assays were performed at $\mathrm{pH} 4.0,5.0,5.5,6.0,6.5$, and 7.0 with a $2 \%$ solution of substrate in $0.1 M$ citrate phosphate buffer for $15 \mathrm{~min}$ at $39^{\circ} \mathrm{C}$. The specific assay procedure used $0.1 \mathrm{~mL}$ of enzyme solution in water and $0.1 \mathrm{~mL}$ of the appropriate $\mathrm{pH}$ citrate phosphate buffer $(0.2 \mathrm{M})$ added to $12 \times 75 \mathrm{~mm}$ tubes in triplicate. Reactions were started by the addition of $0.2 \mathrm{~mL}$ of appropriate substrate and stopped after $15 \mathrm{~min}$ by the addition of 1 $\mathrm{mL}$ of precipitant solution $(95 \%$ ethanol for azo-xylan and $\mathrm{Na} / \mathrm{Zn}$ acetate solution in $\sim 80 \%$ ethanol for azocarboxymethyl cellulose). The reaction mixture was centrifuged at $1,000 \times g$ for $10 \mathrm{~min}$. Two hundred microliters of the supernatant was transferred in duplicate to a microtiter plate and read at $630 \mathrm{~nm}$. Blank tubes contained enzyme, buffer, and precipitants added to test tubes before addition of substrate. Data are presented as Sigma xylanase units, where 1 unit liberated equals $1 \mu \mathrm{mol}$ of reducing sugar measured as xylose equivalents from xylan (Sigma X-0627; Sigma-Aldrich, St. Louis, MO) per min at $\mathrm{pH} 4.5$ at $30^{\circ} \mathrm{C}$ and 1 Sigma cellulase unit liberates $1 \mu \mathrm{mol}$ of glucose from cellulose per $\mathrm{h}$ at $\mathrm{pH} 5.0$ at $37^{\circ} \mathrm{C}$ (2-h assay).

\section{Lactation Study}

Twenty-four multiparous cows (average of $108 \pm 40$ DIM, $40.3 \pm 5.8 \mathrm{~kg}$ of milk/d, $24.6 \pm 3.1 \mathrm{~kg}$ of DMI $/ \mathrm{d}$, $590 \pm 65 \mathrm{~kg}$ of BW) were housed in a free-stall barn with Calan gates (American Calan, Northwood, NH). After a 10-d pretreatment period, cows were blocked on parity, stage of lactation, and milk production and then randomly assigned to 1 of 2 treatments. Cows were offered once daily a TMR consisting of $26 \%$ (DM basis) corn silage, $17 \%$ alfalfa silage, $7 \%$ chopped alfalfa hay, and $50 \%$ concentrate (Table 1) that met nutrient requirements (NRC, 2001). Cows were offered their TMR once daily at $105 \%$ of expected intake to ensure ad libitum consumption. The study was a crossover design with two 21-d periods; the final $7 \mathrm{~d}$ of each period were
Table 1. Composition (\% DM) of the concentrate fed to lactating cows

\begin{tabular}{|c|c|}
\hline Ingredient & $\%$ \\
\hline Corn meal fine & 20.0 \\
\hline Soybean meal, $47.5 \%$ & 18.0 \\
\hline Distillers dried grains & 12.3 \\
\hline Gluten feed & 12.3 \\
\hline Soybean hulls & 7.13 \\
\hline Soybeans, roasted & 5.78 \\
\hline Corn gluten, $60 \% \mathrm{CP}$ & 5.02 \\
\hline Wheat middlings & 3.97 \\
\hline Fat blend $^{1}$ & 3.06 \\
\hline Soybean meal, extruded & 2.78 \\
\hline Limestone, $37 \%$ & 2.54 \\
\hline Molasses blend ${ }^{2}$ & 2.04 \\
\hline Sesquicarbonate & 2.05 \\
\hline Salt & 1.06 \\
\hline Protein blend $^{3}$ & 0.66 \\
\hline Dicalcium phosphate ${ }^{4}$ & 0.50 \\
\hline Urea & 0.41 \\
\hline Magnesium oxide & 0.21 \\
\hline Selenium, $0.06 \%$ & 0.11 \\
\hline Trace minerals ${ }^{5}$ & 0.04 \\
\hline Vitamins $^{6}$ & 0.04 \\
\hline
\end{tabular}

${ }^{1}$ Feed-grade combination of tallow, poultry, and porcine fats.

${ }^{2}$ Contained (DM basis) $0.5 \% \mathrm{Ca}, 0.03 \mathrm{~g}$ of $\mathrm{Cu} / \mathrm{kg}, 5.0 \%$ crude fat, $3.0 \% \mathrm{CP}, 0.50 \mathrm{~g}$ of $\mathrm{I} / \mathrm{kg}, 0.40 \% \mathrm{Mg}, 1.50 \mathrm{Mcal} / \mathrm{kg} \mathrm{NE}, 45.5 \% \mathrm{NSC}$, $3.2 \% \mathrm{~K}, 0.70 \% \mathrm{~S}, 63 \%$ total digestible nutrients, $0.50 \% \mathrm{P}, 0.01 \mathrm{~g}$ of $\mathrm{Zn} / \mathrm{kg}, 0.94$ undegradable intake protein (RUP).

${ }^{3}$ Dried blood meal, hydrolyzed poultry feathers, fish meal, calcium carbonate, and ethoxyquin.

${ }^{4}$ Contained (DM basis) $27 \% \mathrm{Ca}$ and $20 \% \mathrm{P}$.

${ }^{5}$ Contained $2.1 \% \mathrm{Ca}, 1.6 \mathrm{~g}$ of $\mathrm{Co} / \mathrm{kg}, 40 \mathrm{~g}$ of Cu$/ \mathrm{kg}, 4.0 \mathrm{~g}$ of $\mathrm{I} / \mathrm{kg}, 6.0$ $\mathrm{g}$ of $\mathrm{Fe} / \mathrm{kg}, 150 \mathrm{~g}$ of $\mathrm{Mn} / \mathrm{kg}, 13.0 \% \mathrm{~S}$, and $160 \mathrm{~g}$ of $\mathrm{Zn} / \mathrm{kg}$.

${ }^{6}$ Contained (DM basis) $26,400 \mathrm{kIU}$ of vitamin $\mathrm{A} / \mathrm{kg}, 8,800 \mathrm{kIU} / \mathrm{kg}$ of vitamin D, and 165,000 IU of vitamin $\mathrm{E} / \mathrm{kg}$.

used for collection of data and statistical analysis. Cows were fed either an untreated diet top-dressed with $20 \mathrm{~g}$ of limestone carrier or a TMR top-dressed with fibrolytic enzymes ( $10 \mathrm{~g} / \mathrm{cow}$ per day; Alltech). The additives were mixed by hand into the TMR immediately after the TMR was delivered to the Calan gates. The weights of feed offered and refused were recorded each day. Milk production was recorded twice daily at 0600 and 1800 h. During the last day of each week during the study, milk was sampled proportionately to yield on 2 consecutive milkings and analyzed for protein and fat by infrared analyses (MilkoScan, Foss Technology, Hillerød, Denmark). Milk composition was calculated as an average of the 2 milkings and weighted for the proportion of milk produced at each milking. Body weights were recorded on 2 consecutive days at the start and end of each period. Cows had access to fresh water at all times.

Individual samples of the feeds and TMR were collected 3 times each week and composited weekly. The DM content of all feeds was determined by drying representative samples in a forced draft oven at $60^{\circ} \mathrm{C}$ for 48 h. Diets were adjusted weekly based on the DM content of the feeds. The nutrient content of the TMR was ana- 
lyzed once per week. Nitrogen was analyzed (AOAC, 2000) with a Leco FP-528 Nitrogen Combustion Analyzer (Leco, St. Joseph, MI) and CP calculated by multiplication by 6.25. The ADF and NDF content of feeds was determined using the methods of Goering and Van Soest (1970) with the modification of using Whatman 934-AH glass microfiber filters with $1.5-\mu \mathrm{m}$ particle retention (Whatman, Florham Park, NJ). Minerals were analyzed on a pooled sample of the TMR collected throughout the study (AOAC, 2000).

\section{In Vitro NDF Digestion of the TMR}

Equal portions of the weekly TMR (without added enzymes) were pooled to form a single sample. Feed $(0.25 \mathrm{~g})$ was weighed into F57 filter bags (Ankom Technology, Macedon, NY) that had been prerinsed in acetone and dried before use. Bags were incubated at $39^{\circ} \mathrm{C}$ for 24 and $48 \mathrm{~h}$ in an Ankom Daisy II Incubator (Ankom Technology) for the determination of in vitro NDF digestion. The buffer solution, macro and micro mineral mixes, and proportion of ruminal fluid to buffer were as described by Goering and Van Soest (1970). Ruminal fluid was obtained from a fistulated steer that had been fed the same TMR as that offered to the lactating cows. Triplicate bags were incubated without the enzyme mixture or with the equivalent of $0.125,1.25$, or 12.5 $\mathrm{g} / \mathrm{L}$ of ruminal and buffer fluid. Enzyme was added directly to the mixture of ruminal fluid and buffer just before incubation. The lowest dose was set by predicting that a lactating cow would be fed $10 \mathrm{~g}$ of the supplement per day (as in the lactation study) and have a liquid rumen volume of about $80 \mathrm{~L}$ (Gasa et al., 1991). After incubation, the bags were subjected to NDF analysis as described by Van Soest et al. (1991) with the modification of using an Ankom 200 Fiber Analyzer (Ankom Technology).

\section{Lamb Digestion Study}

Eight Dorset rams ( $30 \pm 4 \mathrm{~kg}$ ) were randomly blocked into 1 of 2 treatments based on weight in a crossover design with two 14-d periods; the final $4 \mathrm{~d}$ of each period was used for collection of data. Rams were housed in metabolism crates for the total collection of feces and separation of urine (although urine was not collected). Sheep were fed a complete feed (Agway Inc., Tully, NY) for growing lambs (Table 2). Rams were offered their rations twice daily at ad libitum consumption for an 8$\mathrm{d}$ adaptation period and then cut back to $90 \%$ of ad libitum intake $2 \mathrm{~d}$ before the start of the fecal collection. At each feeding the diet was supplemented with either $4 \mathrm{~g} / \mathrm{d}$ of calcium carbonate (control) or $4 \mathrm{~g} / \mathrm{d}$ of the same fibrolytic mixture of enzymes (applied in its dry form)
Table 2. The nutrient composition (DM basis) of the complete $\operatorname{diet}^{1}$ fed to sheep

\begin{tabular}{lc}
\hline Item & Composition \\
\hline $\mathrm{DM}, \%$ & 91.8 \\
$\mathrm{CP}, \%$ & 16.5 \\
$\mathrm{ADF}, \%$ & 25.6 \\
$\mathrm{NDF}, \%$ & 40.5 \\
$\mathrm{Ca} \%$ & 1.56 \\
$\mathrm{P} \% \%$ & 0.58 \\
$\mathrm{Mg}, \%$ & 0.40 \\
$\mathrm{~K}, \%$ & 1.61 \\
$\mathrm{Na}, \%$ & 0.23 \\
\hline
\end{tabular}

${ }^{1}$ Ingredient formulation was proprietary (Agway Inc., Tully, NY) but the major components were described as processed grain byproducts, roughage by-products, grain by-products, dried bakery waste by-products, cane molasses, condensed whey, and fat product (feed grade).

used in the lactation trial. Feed refused was collected and weighed each day. Rams had access to fresh water at all times. During the collection period, feces were collected and weighed, and $10 \%$ (of fresh weight) was saved each day. The feces were stored frozen at $-20^{\circ} \mathrm{C}$. Frozen feces and feed were composited (10\% on a wetweight basis) for each animal and dried in a forced air oven at $60^{\circ} \mathrm{C}$ for $48 \mathrm{~h}$. Dried samples of feces and feed were ground through a Wiley mill (1-mm screen, Arthur H. Thomas, Philadelphia, PA) and analyzed for lab DM $\left(100^{\circ} \mathrm{C}\right.$ oven for $\left.24 \mathrm{~h}\right)$, ash $\left(600^{\circ} \mathrm{C}\right.$ for $\left.3 \mathrm{~h}\right)$, NDF using sulfite and amylase (Van Soest et al., 1991), and ADF (Robertson and Van Soest, 1981) using an Ankom 200 Fiber Analyzer (Ankom Technology). Crude protein was calculated by multiplying total $\mathrm{N}$ by 6.25 after total combustion in a Leco FP-528 Nitrogen Combustion Analyzer.

\section{Statistical Analyses}

Data from the lactation and sheep studies were analyzed as crossover designs. Data were processed via ANOVA using the GLM procedure of SAS (SAS Institute, 2001). Main effects included sequence, cow(sequence), treatment, and period. Data from the in vitro incubation were analyzed by ANOVA with main effects of enzyme dose and time of incubation and their interactions. Significance was declared when $P<0.05$.

\section{RESULTS AND DISCUSSION}

The enzyme mixture fed to cows and sheep in the current study contained fibrolytic activity over a $\mathrm{pH}$ of 4 to 7 (Figure 1). Specifically, the enzyme mixture showed the highest xylanase activity at a $\mathrm{pH}$ of 4 but the highest cellulase activity at a $\mathrm{pH}$ of 6.5. As a comparison, commercially available xylanase (Sigma; X-3876; lot $126 \mathrm{H} 4097$ ) and cellulase (Sigma; C-9422; lot 


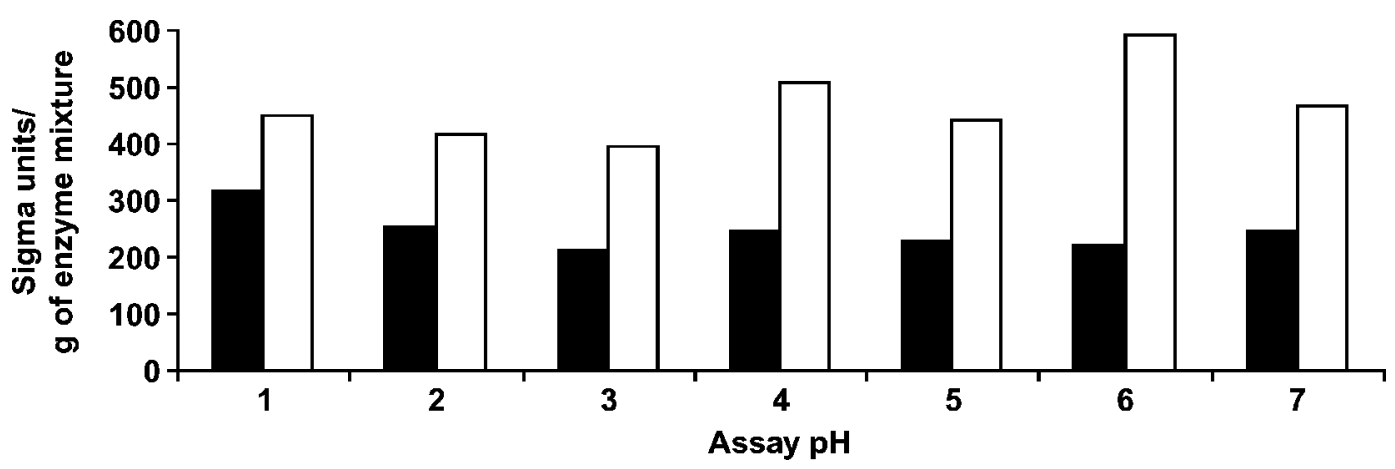

Figure 1. The effect of assay $\mathrm{pH}$ on xylanase activity (solid bars) and cellulase activity (open bars) of the enzyme mixture fed to cattle and sheep. One unit of xylanase activity liberated one micromole of reducing sugar measured as xylose from xylan per minute at the tested $\mathrm{pH}$ at $30^{\circ} \mathrm{C}$. One unit of cellulase activity liberated one micromole of glucose from cellulose per hour at the tested $\mathrm{pH}$ at $37^{\circ} \mathrm{C}$. Standard deviations for each bar are not shown because they were less than \pm 10 .

120K1526) had 332 and 15 times greater average activity (respectively, on a per weight basis) than did the enzyme mixture fed to cows and sheep (data not shown).

The nutrient composition of the TMR fed to lactating cows is shown in Table 3; the TMR met the nutrient requirements for cows used in this study. Cows were of good health and condition throughout the study. Intake of DM was about $24 \mathrm{~kg} / \mathrm{d}$, and milk production averaged about $40 \mathrm{~kg} / \mathrm{d}$ (Table 4). Adding the enzyme mixture to the diet of these cows had no effect on DMI, milk production, or milk composition. Similarly, Ballard et al. (2003) fed a dry enzyme mixture to lactating cows and reported no effects of the additive on intake or milk production and composition. However, Titi (2003) and Ahn et al. (2003) both reported improvements in milk production when cows were fed similar dry enzyme mixtures.

The effect of various doses of enzyme addition on the in vitro digestion of NDF in the TMR is shown in Table

Table 3. Dry matter and nutrient composition (DM basis) of the TMR and forages fed to cows ${ }^{1}$

\begin{tabular}{lcccc}
\hline Item & TMR & $\begin{array}{c}\text { Alfalfa } \\
\text { hay }\end{array}$ & $\begin{array}{c}\text { Alfalfa } \\
\text { silage }\end{array}$ & $\begin{array}{c}\text { Corn } \\
\text { silage }\end{array}$ \\
\hline $\mathrm{DM}, \%$ & 54.2 & 88.7 & 33.6 & 43.8 \\
$\mathrm{NE}_{\mathrm{L}}{ }^{2}{ }^{\mathrm{M}} \mathrm{Mcal} / \mathrm{kg}$ & 1.71 & - & - & - \\
$\mathrm{CP} \%$ & 18.2 & 17.6 & 17.8 & 8.1 \\
$\mathrm{ADF}, \%$ & 20.5 & 28.2 & 26.5 & 25.8 \\
$\mathrm{NDF}, \%$ & 31.4 & 47.6 & 46.3 & 43.0 \\
$\mathrm{Ca} \%$ & 0.95 & - & - & - \\
$\mathrm{P}, \%$ & 0.37 & - & - & - \\
$\mathrm{Mg} \%$ & 0.34 & - & - & - \\
$\mathrm{K}, \%$ & 1.73 & - & - & - \\
$\mathrm{Na}, \%$ & 0.43 & - & - & - \\
\hline
\end{tabular}

\footnotetext{
${ }^{1}$ Average analysis from 6 samples collected during the lactation trial except that minerals were analyzed on a single composite sample for the TMR.

${ }^{2}$ Calculated from dietary ingredients.
}

5. Digestion of NDF averaged $39.6 \%$ for all treatments after $24 \mathrm{~h}$ of incubation and increased to an average of $53.7 \%$ after $48 \mathrm{~h}$. The later value is within the range of expected NDF digestibility values for a TMR as reported by Hoffman (2004). Addition of the enzyme mixture, regardless of dose, had no effect on the NDF digestion of the TMR at either time point.

Sheep were fed a diet supplemented with the same enzyme and carrier supplement offered to the lactating cows. The ratio of enzyme (g) to DMI (kg) was higher in sheep (2.91) than in cows ( 0.41) to test the ability of a greater dose of enzymes to improve digestibility. However, supplementation with enzymes had no effect on DM, ADF, NDF, or $\mathrm{N}$ digestion (Table 6). These results are in contrast to the findings of Pinor-Rodriguez et al. (2002), who reported that addition of enzymes improved NDF digestion and $\mathrm{N}$ retention in lambs fed alfalfa hay.

The specific reasons for a lack of effect of the dry enzyme mixture applied in this study on lactating cows and on sheep are unknown. Enzymes mixtures can dif-

Table 4. Effect of feeding cows a dry enzyme mixture on DMI, milk production, and milk composition

\begin{tabular}{lcccc}
\hline Item & Control & Enzyme $^{1}$ & SEM & $P<$ \\
\hline DMI, kg/d & 24.4 & 23.8 & 0.7 & 0.54 \\
Milk, & & & & \\
Yield, kg/d & 40.2 & 40.1 & 0.4 & 0.79 \\
Fat, \% & 3.39 & 3.54 & 0.10 & 0.29 \\
Fat, kg/d & 1.36 & 1.42 & 0.09 & 0.69 \\
Protein, \% & 2.94 & 2.92 & 0.02 & 0.69 \\
Protein, kg/d & 1.18 & 1.17 & 0.01 & 0.89 \\
Lactose, \% & 4.81 & 4.83 & 0.02 & 0.85 \\
$3.5 \%$ FCM, kg/d & 39.3 & 40.4 & 0.7 & 0.26 \\
SCC, $\times 1,000 / \mathrm{mL}$ & 182 & 234 & 53 & 0.49 \\
BW, kg & 591 & 597 & 20 & 0.85 \\
\hline
\end{tabular}

${ }^{1}$ Cows supplemented with $10 \mathrm{~g} / \mathrm{d}$ of a dry enzyme mixture. 
Table 5. The effect of a dry enzyme addition on in vitro NDF digestion of a $\mathrm{TMR}^{1}$

\begin{tabular}{lccccc}
\hline \multirow{2}{*}{$\begin{array}{l}\text { Incubation } \\
\text { time }\end{array}$} & \multicolumn{4}{c}{ Treatment $^{2}$} & \\
\cline { 2 - 5 } & Control & ENZ, 1× & ENZ, 10× & ENZ, 100× & SEM \\
\hline $24 \mathrm{~h}$ & 41.5 & 38.9 & 40.1 & 38.0 & 2.6 \\
$48 \mathrm{~h}$ & 54.8 & 53.9 & 53.0 & 53.0 & 3.1 \\
\hline
\end{tabular}

${ }^{1}$ The TMR was a pooled composite of samples collected over the lactation trial.

${ }^{2} \mathrm{ENZ}=$ a dry enzyme mixture containing cellulase and xylanase activity; $1 \times=0.125 \mathrm{~g}$ of enzyme mixture per $\mathrm{L}$ of ruminal fluid and buffer; $10 \times=1.25 \mathrm{~g}$ of enzyme mixture per $\mathrm{L}$ of ruminal fluid and buffer; $100 \times=12.5 \mathrm{~g}$ of enzyme mixture per $\mathrm{L}$ of ruminal fluid and buffer.

fer in their ability to degrade specific types of substrates (Colombatto et al., 2003) and may have different rumen stabilities (Morgavi et al., 2000b) that may explain some of the inconsistent effects when enzymes have been added to diets for ruminants. The mixture of enzymes and their application rates as well as the type of feeds and maturity of forages in the diets may determine how effective enzymes are in improving animal performance. How enzymes are applied to feeds has also been suggested as an important factor determining their efficacy (Dean et al., 2006). Specifically, Beauchemin et al. (2004) proposed that pretreatment of dry feeds with enzymes applied in a liquid form was important because it created a stable feed-enzyme complex. Upon entering the rumen, enzymes attached to substrate might be less prone to inactivation from proteolytic processes in the rumen. Morgavi et al. (2000a) suggested that interactions between the enzymes and substrate caused a "scarring" of the fiber particles that resulted in improved attachment by fibrolytic microbes in the rumen. Several studies have shown that enzymes are less effective if infused directly into the rumen (Lewis et al., 1999; Wang et al., 2001). However, Tricarico et al. (1998) reported that the addition of xylanase and cellulase enzyme preparations directly to in vitro ruminal fermentations improved the digestibility of fescue hay.

Table 6. Intake and apparent digestion of nutrients from lambs fed a complete diet supplemented with or without an enzyme mixture

\begin{tabular}{lcccc}
\hline Item & Control & Enzyme $^{1}$ & SEM & $P<$ \\
\hline DMI, g/d & 1,358 & 1,365 & 7 & 0.43 \\
DM digestion, \% & 63.5 & 62.7 & 1.5 & 0.79 \\
ADF digestion, \% & 52.1 & 51.0 & 3.4 & 0.87 \\
NDF digestion, \% & 53.7 & 52.7 & 2.4 & 0.83 \\
N digestion, \% & 66.5 & 66.3 & 1.2 & 0.89 \\
\hline
\end{tabular}

${ }^{1}$ Sheep were supplemented with $4 \mathrm{~g} / \mathrm{d}$ of a dry fibrolytic enzyme mixture.

\section{CONCLUSIONS}

The enzyme mixture used in these studies contained xylanase and cellulase activities over a wide range of $\mathrm{pH}$. However, when it was mixed as a dry supplement into a TMR for dairy cattle, it did not enhance feed intake, improve milk production, or change milk composition from lactating cows. The enzyme mixture also had no effect on the in vitro digestion of TMR even when added in high doses. When added to a diet for lambs, nutrient digestion was unaffected by the enzyme mixture. The reasons for a lack of response are unknown at this time.

\section{ACKNOWLEDGMENTS}

This study was partially supported by Alltech Biotechnology (Nicholasville, KY). The authors wish to thank Richard Morris, Jeanne Neylon, Janey Lazartic, and Christy Taylor for care and feeding of the animals.

\section{REFERENCES}

Ahn, J. H., Y. J. Kim, and H. J. Kim. 2003. Effects of fibrolytic enzyme addition on ruminal fermentation, milk yield and milk composition of dairy cows. J. Anim. Sci. Technol. 45:131-142.

AOAC. 2000. Official Methods of Analysis. 17th ed. Association of Official Analytical Chemists International, Gaithersburg, MD.

Ballard, C. S., M. P. Carter, K. W. Contach, C. J. Sniffen, T. Sato, K. Uchida, A. Teo, U. D. Nhan, and T. H. Meng. 2003. Feeding fibrolytic enzymes to enhance DM and nutrient digestion and milk production by dairy cows. J. Dairy Sci. 86(Suppl. 1):150. (Abstr.)

Beauchemin, K. A., D. Colombatto, D. P. Morgavi, W. Z. Yang, and L. M. Rode. 2004. Mode of action of exogenous cell wall degrading enzymes for ruminants. Can. J. Anim. Sci. 84:13-22.

Beauchemin, K. A., L. M. Rode, M. Maekawa, D. P. Morgavi, and R. Kampen. 2000. Evaluation of a nonstarch polysaccharidase feed enzyme in dairy cow diets. J. Dairy Sci. 83:543-553.

Colombatto, D., F. L. Mould, M. K. Bhat, and E. Owen. 2003. Use of fibrolytic enzymes to improve the nutritive value of ruminant diets: A biochemical and in vitro rumen degradation assessment. Anim. Feed Sci. Technol. 107:201-209.

Dean, D. B., A. T. Adesogan, C. R. Staples, S. C. Kim, and R. Littell. 2006. Effect of method of adding a fibrolytic enzyme to a dairy cow diet on ruminal fermentation and TMR degradation. J. Dairy Sci. 89(Suppl. 1):405. (Abstr.)

FASS. 1999. Guide for the Care and Use of Agricultural Animals in Agricultural Research and Teaching. Federation of Animal Science Societies, Savoy, IL.

Fontes, C. M. G. A., J. Hall, B. H. Hirst, G. P. Hazelwood, and H. J. Gilbert. 1995. The resistance of cellulases and xylanases to proteolytic inactivation. Appl. Microbiol. Biotechnol. 43:52-57.

Gasa, J., K. Holtenius, J. D. Sutton, M. S. Dhanoa, and D. J. Napper. 1991. Rumen fill and digesta kinetics in lactating Friesian cows given two levels of concentrates with two types of grass silage ad lib. Br. J. Nutr. 66:381-398.

Goering, H. K., and P. J. Van Soest. 1970. Forage Fiber Analyses (Apparatus, Reagents, Procedures, and Some Applications). Agric. Handbook No. 379. ARS-USDA, Washington, DC.

Hoffman, P. C. 2004. Understanding and using forage test results. Page 113 in Proc. Four-State Professional Dairy Management Seminar. Midwest Plan Service, Ames, IA.

Hristov, A. N., T. A. McAllister, and K.-J. Cheng. 2000. Intraruminal supplementation with increasing levels of exogenous polysaccharide-degrading enzymes: Effects on nutrient digestion in cattle fed a barley grain diet. J. Anim. Sci. 78:477-487. 
Kung, L., Jr., M. A. Cohen, L. M. Rode, and R. J. Treacher. 2002. The effect of fibrolytic enzymes sprayed onto forages and fed in a total mixed ration to lactating dairy cows. J. Dairy Sci. 85:2396-2402.

Lewis, G. E., W. K. Sanchez, C. W. Hunt, M. A. Guy, G. T. Protchard, B. I. Swanson, and R. J. Treacher. 1999. Effect of direct-fed fibrolytic enzymes on the lactational performance of dairy cows. J. Dairy Sci. 82:611-617.

Morgavi, D. P., K. A. Beauchemin, V. L. Nsereko, L. M. Rode, A. D. Iwasaa, W. Z. Yang, T. A. McAllister, and Y. Wang. 2000a. Synergy between ruminal fibrolytic enzymes and enzymes from Trichoderma longibrachiatum. J. Dairy Sci. 83:1310-1321.

Morgavi, D. P., C. J. Newbold, D. E. Beever, and R. J. Wallace. 2000b. Stability and stabilization of potential feed additive enzymes in rumen fluid. Enzym. Microbiol. Technol. 26:171-177.

NRC. 2001. Nutrient Requirements of Dairy Cattle. 7th rev. ed. Natl. Acad. Sci., Washington, DC.

Pinor-Rodriguez, J. M., S. S. Gonzalez, G. D. Mendoza, R. Barcena, M. A. Cobos, A. Hernandez, and M. E. Ortega. 2002. Effect of exogenous fibrolytic enzyme on ruminal fermentation and digestibility of alfalfa and rye-grass hay fed to lambs. J. Anim. Sci. 80:3016-3020.

Robertson, J. B., and P. J. Van Soest. 1981. The detergent system of analysis and its application to human foods. Pages 123-158 in The Analysis of Dietary Fiber in Food. W. P. T. James and O. Theander, ed. Marcel Dekker Inc., New York, NY.

Rode, L. M., W. Z. Yang, and K. A. Beauchemin. 1999. Fibrolytic enzyme supplements for dairy cows in early lactation. J. Dairy Sci. 82:2121-2126.

SAS Institute. 2001. SAS/STAT User's Guide. Version 8.2. SAS Institute Inc., Cary, NC.
Schingoethe, D. J., G. A. Stegman, and R. J. Treacher. 1999. Response of lactating dairy cows to a cellulase and xylanase enzyme mixture applied to forages at the time of feeding. J. Dairy Sci. 82:996-1003.

Stokes, M. R., and S. Zheng. 1995. The use of carbohydrase enzymes as feed additives for early lactation cows. Page 35 in Proc. 23 Biennial Conf. on Rumen Function, Chicago, IL.

Titi, H. H. 2003. Evaluation of feeding a fibrolytic enzyme to lactating dairy cows on their lactational performance during early lactation. Asian-australas. J. Anim. Sci. 16:677-684.

Tricarico, J. M., K. A. Dawson, and K. E. Newman. 1998. Effects of an exogenous microbial enzyme preparation (Fibrozyme) on ruminal digestion of fescue hay. J. Anim. Sci. 81(Suppl. 1):289. (Abstr.)

Van Soest, P. J., J. B. Robertson, and B. A. Lewis. 1991. Methods for dietary fiber, neutral detergent fiber, and nonstarch polysaccharides in relation to animal nutrition. J. Dairy Sci. 74:35833597.

Wang, Y., T. A. McAllister, L. M. Rode, K. A. Beauchemin, D. P. Morgavi, V. L. Nserko, A. D. Iwaasa, and W. Yang. 2001. Effects of an exogenous enzyme preparation on microbial protein synthesis, enzyme activity and attachment to feed in the Rumen Simulation Technique (Rusitec). Br. J. Nutr. 85:325-332.

Yang, W. Z., K. A. Beauchemin, and L. M. Rode. 1999. Effects of an enzyme feed additive on extent of digestion and milk production of lactating dairy cows. J. Dairy Sci. 82:391-403.

Zinn, R. A., and J. Salinas. 1999. Influence of Fibrozyme in digestive function and growth performance of feedlot steers fed a 78\% concentrate-growing diet. Pages 313-319 in Proc. Annu. Symp: Biotechnology in the Feed Industry. T. P. Lyons and K. A. Jacques, ed. Nottingham University Press, Loughborough, UK. 